\title{
ROLE OF CARBOHYDRATES AND PROTEINS IN MAXIMIZING PRODUCTIVITY IN ALPHITOBIUS DIAPERINUS (COLEOPTERA TENEBRIONIDAE)
}

\author{
(*) Department of Chemical, Biological, Pharmaceutical and Environmental Science University of Messina \\ (*) Corresponding author: Cosimo Baviera, Department of Chemical, Biological, Pharmaceutical and Environmental \\ Science University of Messina, Viale Ferdinando Stagno d'Alcontres, 17; 98164 Messina; e-mail: cbaviera@unime.it
}

Ricciardi C., Baviera C. - Role of carbohydrates and proteins in maximizing productivity in Alphitobius diaperinus (Coleoptera Tenebrionidae).

Among all Tenebrionidae beetles Alphitobius diaperinus is considered a good choice for high-scale facility production of feed and food. It is widely considered that studies regarding the impact of the different dietary components on growth performances are very few and focused only on certain aspects, e.g. problems connected to the harmfulness of this species for stored products (rearing to test insecticides, studies about dietary preferences regarding different cereals). The real role of the different dietary components was never evaluated in order to better comprehend how to project diets that maximize productivity (maximum number of specimen as function of time). Research on the role of proteins and carbohydrates ascertained that a high protein content is required to obtain the best growth performances for this species. Carbohydrates also play a key role, though secondary to proteins.

The diets thus obtained establish an important starting point for future formulations aimed at obtaining useful insects for feed and also for human consumption, soon to be legalized worldwide.

KEY WoRDS: Alphitobius sp., artificial diets, beetles, lesser mealworm, mass rearing, Tenebrionidae.

\section{INTRODUCTION}

Nowadays insects of many orders are considered possible feed for livestock, aquaculture and human consumption (food). Considering aquaculture, many species have been reared successfully and a percentage of commercial feed have been replaced with insect flours. Among the species that produced good results we have: Oncorhynchus mykiss Walbaum (GASCO et al., 2014a), Sparus aurata L. (Piccolo et al., 2014), Dicentrarchus labrax L. (GASCO et al., 2014b), Ictalurus punctatus Rafinesque (BONDARI and SHEPPARD, 1981; BONDARI and SHEPPARD, 1987), Oreochromis niloticu L. (BONDARI and SHEPPARD, 1981; BONDARI and SHEPPARD, 1987), Clarias gariepinus Burchell (FASAKIN et al., 2003), Cyprinus carpio L. (OGunJI et al., 2007). Although insects are not so commonly used as livestock feed, there are some important studies about rearing some of the major species in aviculture: Gallus gallus domesticus L. (HwANGBO et al., 2009, Ballitoc and Sun, 2013; De Marco et al., 2014; Schiavone et al., 2014;) and Meleagris spp. L. (ZuidHoF et al., 2003). Also pig farming is showing an increasing interest in substituting fishmeal with insect flour but the most recent studies are outdated (NEWTON et al., 1977; BAYANDinAa and InKINA, 1980; Viroje and MALIN, 1989; NewTON et al., 2005; AdENIJI, 2008; ).

Insects belonging to many orders are consumed by humans worldwide, but in the Western world they do not form a significant part of the average diet. People in most Western countries find entomophagy disgusting (RozIN and FALlON, 1987; YeN, 2009). The reasons depend heavily on culture, which has a major effect on food habits. Culture defines what is edible and what isn't (Mela, 1999). In short, the opinions on entomophagy are a question of culture (MignON, 2002). Furthermore, on average the size of insects in the Western world is smaller than e.g. in tropical countries, as it is related to metabolism and at higher temperatures, metabolism is faster (GASTON and CHOwN, 1999).

The demand of animal-derived proteins is currently rising due to a growing world population. Also the environmental impact of livestock rearing facilities is to be considered and the consumption of insects receives increasing attention as an alternative source of protein (VAN HUIS, 2013; VAN HUIS et al., 2013).

In fact, livestock production is associated with high $\mathrm{CO}_{2}$ emissions, land air and water pollution by zootechnical sewage and loss of biodiversity (STEINFELD et al., 2006; MeKOnNen and Hoekstra, 2010). Insects, unlike homeotherms, have faster growing rates and a higher feed conversion efficiency (NAKAGAKI and DEFOLIART, 1991). Furthermore, compared to conventional livestock, insect facilities require less land space (OONINCX and DE BOER, 2012), use less water (VAN HuIs, 2013) and $\mathrm{CO}_{2}$ emissions are smaller (OONINCX et al., 2010).

In the Western world, unlike Asia or Africa, insects are grown in closed farming systems rather than harvested from nature. The most common beetle species reared in the Western world belong to the Tenebrionidae family: Tenebrio molitor L.; Zophobas atratus Fab.; Alphitobius diaperinus Panzer. These insects are commonly produced on mixed grain diets. There is extensive literature about Tenebrio molitor's mass production (GHALY and ALKOAIK, 2009; VAN HuIs, 2013), but significantly less about the other two species.

Insect growth rate and body composition, and hence nutritional quality, can be altered by diet (DAvis and SosulsKi, 1974; ANDERSON, 2000;). Documentation on dietary effects on the growth and chemical composition of T. molitor is widely available (DAVIS and SosULSKI, 1974; 
RAMOS-EloRduY et al., 2002; GAO et al., 2010; MorALESRAMOS et al., 2010;), but less so for A. diaperinus (HosEN et al. 2004; VAN BROEKHOVEN et al., 2015).

$A$. diaperinus, due to its smaller size and faster biological cycle, compared to T. molitor and $Z$. atratus, is a better choice as a model species for a rearing facility. In fact $A$. diaperinus can be easily reared to obtain protein flour for human consumption or as feed for fish or farm animals.

The purpose of this study is to evaluate different biological aspects of diets on an A. diaperinus colony. For this goal we evaluated:

a) the role of high or low proteins and carbohydrates in artificial diets in rearing performance of $A$. diaperinus;

b) the impact of diet on the overall productivity of a standard colony;

c) the impact of diet on the daily productivity (by quantity) of a standard colony;

d) the impact of diet on the daily productivity (by weight) of a standard colony;

e) the impact of diet on the mortality of pupae;

f) the impact of diet on the metamorphosis time from prepupae to pupae;

g) the impact of diet on the metamorphosis time from pupae to adults;

h) the impact of diet on the life cycle length from sexually mature adults to newly emerged adults.

\section{MATERIALS AND METHODS}

\section{INSECTS}

Insects were bought from Kreca (Ermelo, The Netherlands) and reared in a climatic chamber. There are some studies on the correlation between the $A$. diaperinus biological cycle and temperature (DASS et al., 1984; CherNAKI-LefFer et al., 2001; Silva et al., 2005). The adopted rearing conditions were optimal for the specie and consisted in a temperature of $30^{\circ} \mathrm{C}, 65 \% \mathrm{RH}$ and $12 \mathrm{~h}$ photoperiod (SALLET et al., 2013).

\section{Diet Preparation}

In this study three different diets were used, based on a different ratio of seeds, cereals and legumes. The choice of using cereals as primary carbohydrate source depended on the high digestibility of cereal starch for Tenebrionidae (APplebaum, 1966; Mereiles et al., 2009).

The diets were elaborated considering three main macronutrient templates: HPHC, LPHC and HPLC $(\mathrm{HP}=$ high protein, $\mathrm{HC}=$ high carbohydrates, $\mathrm{LP}=$ low protein, LC=low carbohydrates). The components of the diets were finely ground three times and sieved until the needed granulometry was obtained (60 mesh). Each component was then weighed and added in the appropriate ratio to form three macronutrient template diets. Each template was mechanically blended to assure homogeneity.

Parallel to diet preparation, water gel was also produced to provide a reliable water source. Water gel was prepared adding $1 \%$ weight content agar-agar to water and boiling the solution; the solution was then left to cool down in a steel container; temperature was monitored and Methyl 4hydroxybenzoate, in $0.1 \%$ weight content was added when it reached $60^{\circ} \mathrm{C}$. The choice of agar-agar as gelling agent was made considering its high water activity value (COHEN, 2004). This choice was influenced by the need to avoid unchecked provision of nutrients, which would have influenced final results, as would have using carrots or apple slices (RICE \& LAMBKIN, 2009; VAN BROEKHOVEN et al., 2015), although the choice of using carrots in the van Broekhoven (2015) experiment could be viable due the different experiment setup.

Methyl 4-hydroxybenzoate is a common food preservative with an anti-molding action; its content was chosen according to its effective concentration, depending on the water's pH (SINGH and House, 1970a; SINGH and House, 1970b; FunKE, 1983).

\section{Nutrient Composition Of The Diets}

As previously introduced, diets were prepared following three different templates: HCHP, LCHP and HCLP.

The HCHP template was characterized by a carbohydrate content of $55 \%$, protein content of $23 \%$ and lipid content of $10 \%$; the LCHP template was characterized by a carbohydrate content of $40 \%$, protein content of $24,4 \%$ and lipid content of $10 \%$; the HCLP template was characterized by a carbohydrate content of $61,6 \%$, protein content of $12,2 \%$ and lipid content of $7,6 \%$. The water content was comparable in the HCHP and LCHP templates $(7,8 \%$ and $8 \%$ respectively) and slightly higher in the HCLP $(9,5 \%)$, (USDA DATABASE, 2016).

\section{GROWTH AND DEVELOPMENT}

The standard colonies were composed by twenty adults with a sex ratio of 50/50 reared in a plastic container box $(20 \times 12 \times 7 \mathrm{~cm})$ with aeration holes on top. In each container $100 \mathrm{~g}$ of diet and a block of water gel $(25 \mathrm{~g})$ were present. A. diaperinus adults were left in the containers throughout the experimental period and females were free to lay eggs continuously in the feeding substrate. Newly hatched larvae and adults were allowed to feed freely until diet depleted. For each diet the experimental period was considered since first adults mating occurred to the last pupa's metamorphosis into adult observed. For each diet, five replications were done. Each container was monitored three times a week, on alternate days. First adults mating, eggs hatching times (first larval appearance) and first prepupal appearance were recorded. During each check prepupae (the nonfeeding, inactive stage between the larval period and the pupal period) and pupae were removed from the container, isolated and counted. For all the pre-pupae the metamorphosis time into pupae was recorded. All the pupae were weighed. The pre-pupae and pupae collected were also checked three times a week, until metamorphosis into pupae and adults occurred and mortality and metamorphosis times were recorded.

\section{FEED CONVERSION EFFICIENCY}

In order to determine feed conversion efficiency for each diet, feed conversion ratio was calculated as (VAN BROEKHOVEN et al., 2015):

$$
F C R=\left(\frac{\text { weight of ingested food }}{\text { weight gained }}\right)
$$

\section{ELABORATION OF DATA}

Data collected were used to elaborate cumulative frequency curves of pre-pupae, pupae and adult quantity and to elaborate cumulative frequency curves of pupal weight, each curve as a function of time. Average pupal weight was also evaluated as depletion of each substrate progressed. Furthermore the average pupal daily yield was evaluated, calculated since the beginning of each replication, to correlate quantity with the time needed to obtain it. Other features taken into consideration were: pre- 
pupal metamorphosis time (time that pre-pupae need to became pupae), percentage of emerged adults compared to the overall pupal number, pupal metamorphosis time (time that pupae need to became adults), adult mortality and first adults appearance time, calculated since the first adults mating occurred to the first newly emerged adults.

\section{STATISTICAL ANALYSIS}

Weight, quantity and average pupal daily yield values of pre-pupae, pupae and adults presented normal data distribution and were analyzed by One way Analysis of Variance (ANOVA) at a significance level of 0.05 , followed by a Šidák correction for multiple comparisons. Also prepupal metamorphosis time, adult mortality, pupal metamorphosis time and first adults appearance time were normally distributed.

FCR was not normally distributed and then analyzed by a Kruskal-Wallis test at a significance level of 0.05 , followed by Mann-Whitney U tests with applying Šidák correction.

All statistical analyses were performed using IBM SPSS statistics v.20.

\section{RESULTS AND DISCUSSION}

\section{PRE-PUPAL QUANTITY}

Pre-Pupal quantity values analyzed were dependent on the substrate type. We obtained a $\mathrm{p}$-value $<0.0000001$ indicating a statistical significance: HCHP and LCHP templates did not show differences, while HCHP vs HCLP $(\mathrm{p}<0.0002)$ and LCHP vs HCLP $(\mathrm{p}<0.0002)$ did. Average pre-pupal quantity, considered at depleted substrate was, 702,2 for HCHP, 570 for LCHP and 128,2 specimens for
HCLP. Average pre-pupal quantity, considered at maximum average slope of cumulative frequency curve, was 649 units for HCHP, 479.4 units for LCHP, 121.4 units for HCLP.

The evidence just described is shown in Fig. I.

\section{PRE-PUPAL METAMORPHOSIS TIME}

Pre-pupal metamorphosis times did not show statistical significance. For the majority of the specimens metamorphosis times were inferior to 2 days: for HCHP only $1.31 \%$ of pre-pupae spent more than 2 days to metamorphosize, for LCHP only $7.3 \%$ and for HCLP only $9.94 \%$.

\section{PupAl WEIGHT}

The total Pupal weight (grams), calculated at depletion of substrate, was heavily dependent on the diet template $(\mathrm{p}<$ 0.000001): HCHP weights were higher than the ones obtained from LCHP $(p<0.0008)$ and also higher than the HCLP ones $(p<0.0002)$; LCHP was higher than HCLP $(p<0.0008)$. The average total pupal weight was 22.6083 grams for the HCHP template, 12.6205 grams for the LCHP template and 2.5982 grams for the HCLP template. Fig.II, 1 shows these final values and furthermore the evolution of average total weight in the three templates as a function of time.

Average pupal weight, calculated at depletion of substrate, was also heavily dependent on the diet template $(\mathrm{p}<0.00001)$ : the HCHP individual weights were higher than ones obtained from LCHP $(p=0.001042)$ and also higher than the HCLP ones $(p<0.0002)$; LCHP was higher than HCLP $(p=0.002209)$. The average individual weight was 0.0236 grams for the HCHP template, 0.0197 grams for the LCHP template and 0.0170 grams for the HCLP template.

The total Pupal weight, calculated at the maximum

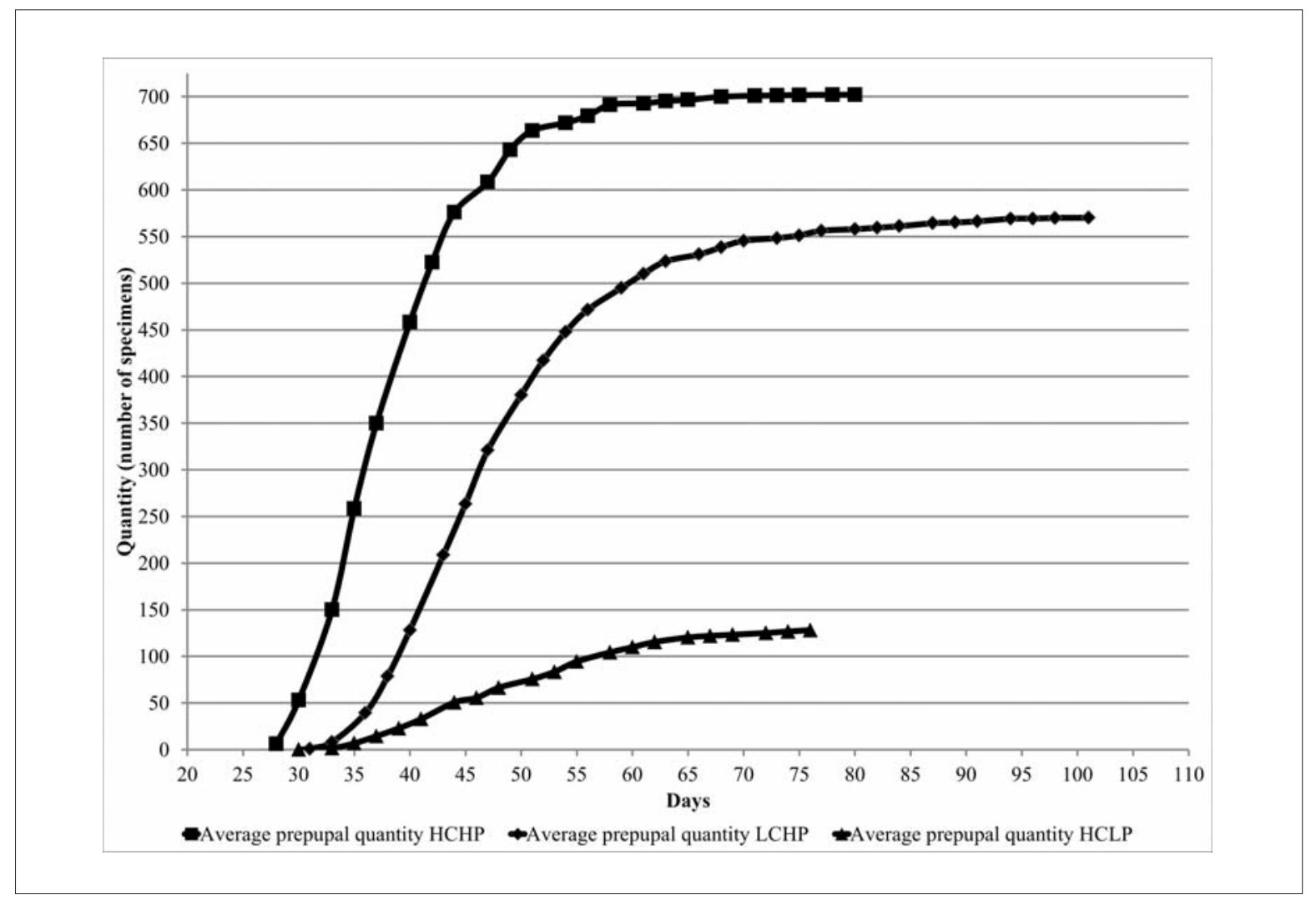

Fig. I - Cumulative frequency curve of average pre-pupal quantity in diet templates (HCHP= high carbohydrates, high proteins; $\mathrm{LCHP}=$ low carbohydrates, high proteins; $\mathrm{HCLP}=$ high carbohydrates, low proteins). 


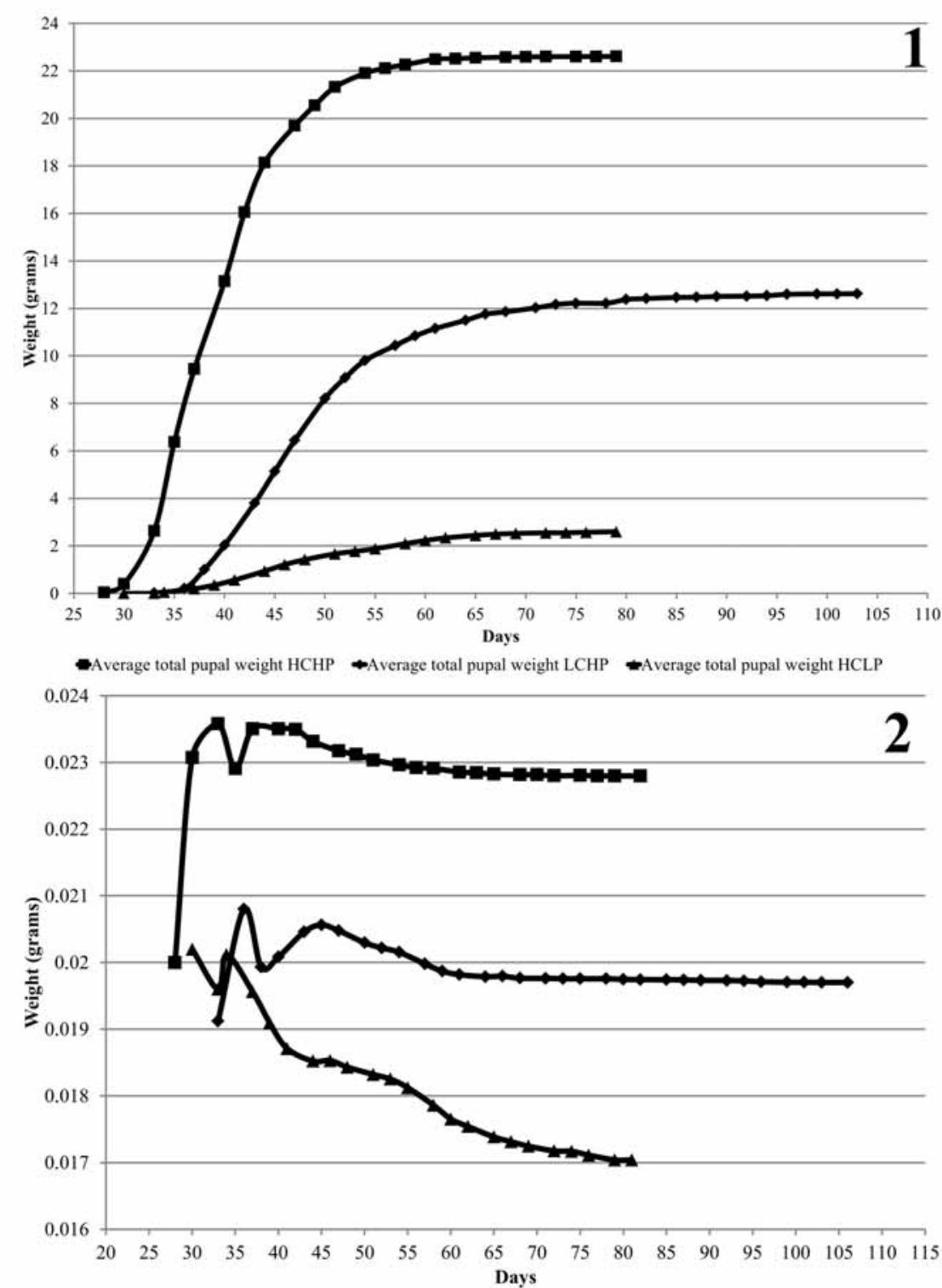

-Average ind. pupal weight HCHP —Average ind. pupal weight LCHP —Average ind. pupal weight HCLP

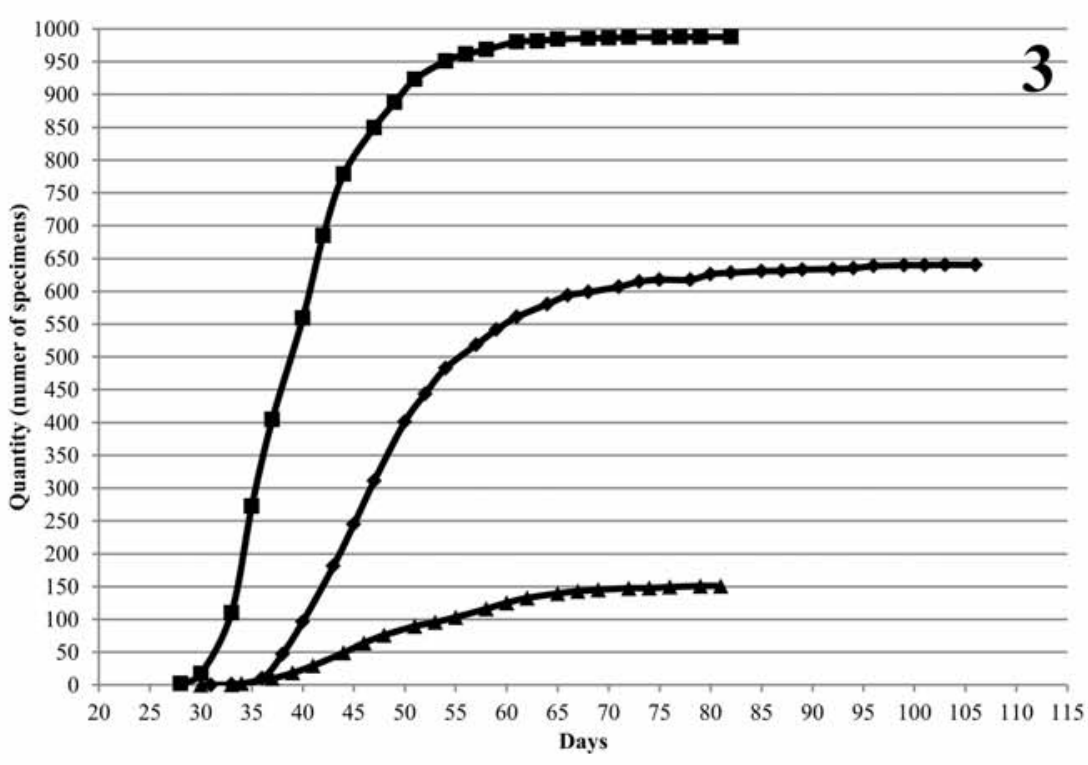

Fig. II - (1) Cumulative frequency curves of average pupal weight in diet templates, (2) Average individual pupal weight as function of time in diet templates, (3) Cumulative frequency curves of average pupal quantity in diet templates (HCHP= high carbohydrates, high proteins; $\mathrm{LCHP}=$ low carbohydrates, high proteins; HCLP $=$ high carbohydrates, low proteins). 
average slope of the cumulative frequency curve, was also heavily dependent on the diet template $(p<0.000001)$ : the HCHP weights were higher than the ones obtained from LCHP $(\mathrm{p}<0.0003)$ and also higher than the HCLP ones $(\mathrm{p}<0.0002)$; LCHP was higher than HCLP $(\mathrm{p}<0.0005)$. The average total pupal weight was 20.3843 grams for the HCHP template, 10.9735 grams for the LCHP template and 2.4447 grams for the HCLP template.

The individual pupal weight, calculated at the maximum average slope of the cumulative frequency curve, was also heavily dependent on the diet template $(p<0.000006)$ : the HCHP individual weights were higher than the ones obtained from LCHP $(\mathrm{p}=0.00144)$ and also higher than the HCLP ones $(p<0.0002)$; LCHP was higher than HCLP $(p<0.004)$. The average individual weight was 0.0231 grams for the HCHP template, 0.0200 grams for the LCHP template and 0.0172 grams for the HCLP template.

Fig.II, 2 shows how values change drastically as time goes by and the similarity of shapes between HCHP and LCHP curves. In fact, these two curves tend to maintain a constant average individual weight in the terminal part of the curve, while the HCLP curve tends to decrease constantly, stopping only in the end.

\section{PUPAL QUANTITY}

Each template type had very different yields $(p<0.000001)$ : among all templates, HCHP had higher yields compared to LCHP ( $p<0.003)$ and HCLP $(p<0.0002)$. Considering yields at depleted substrate, the HCHP average yields were 987.8 units, the LCHP average yields were 640.4 units and the HCLP average yields were 151 units.

The values expressed above can be viewed in Fig. II, 3, representing the cumulative curve of pupal quantity. It is also evident that the slope is higher for HCHP than for LCHP and HCLP.

If we consider average pupal quantity at the maximum average slope of the cumulative frequency curve, HCHP has the highest values compared to LCHP $(\mathrm{p}<0.0005)$ and HCLP $(\mathrm{p}<0.0002)$, with 890 units, 550.8 units and 142.8 units respectively.

\section{AVERAGE PUPAL DAILY QUANTITY YIELDS}

Pupal daily quantity yields are strongly dependent on the diet template; considering values at depleted substrate time, we obtain a $\mathrm{p}$-value $<0.0000005$; HCHP template had the highest average yields compared to LCHP $(p<0.0003)$ and HCLP $(\mathrm{p}<0.0002)$ with 12.50 pupae/day, 6.15 pupae/day and 1.87 pupae/day respectively. Similarly, comparing maximum average daily pupal yields, we obtain a pvalue $<0.0000004$; HCHP template had again the highest yields compared to LCHP $(p<0.0003)$ and HCLP $(\mathrm{p}<0.0002)$ with 18.12 pupae/day, 9.07 pupae/day and 2.15 pupae/day respectively (Fig. III, 1).

\section{AVERAGE PUPAL DAILY WEIGHT YIELDS}

Pupal daily weight yields are also dependent on the diet template; considering values at depleted substrate time, we obtain a p-value $<0.000001$; HCHP template had the highest yields followed by LCHP and HCLP with 0.2861 grams/day, 0.1229 grams/day and 0.0327 grams/day respectively. Similarly, comparing maximum average daily pupal yields, we obtain a p-value $<0.000001$; the HCHP template had again the highest yields followed by LCHP and HCLP with 0.4194 grams/day, 0.1836 grams/day and 0.03787 grams/day respectively. Fig. III, 2 shows what described above and it reflects the shape of average pupal daily quantity (Fig. III, 1).
PUPAL METAMORPHOSIS TIME

Diet did not influence pupal metamorphosis times in a statistically significant way: it was 4.78 days for HCHP, 5.3 for LCHP and 5.01 for HCLP. According to data from the literature, the average metamorphosis time is four to seven days (CHERNAKI-LEFFER et al., 2001; SALLET et al, 2013). In particular for HCHP $23.82 \%$ of the specimens spent 4 days, $56.8 \%$ spent 5 days and $11.13 \%$ spent 7 days; for LCHP $19.15 \%$ spent 4 days, $43.42 \%$ spent 5 days and $21.19 \%$ spent 7 days; for HCLP $18.35 \%$ spent 4 days, $45.03 \%$ spent 5 days and $19,53 \%$ spent 7 days (Fig. IV).

\section{ADULT QUANTITY}

Also for emerged adults, quantity was dependent on the template type $(\mathrm{p}<0.0000008)$ : the HCHP template had higher yields compared to LCHP $(\mathrm{p}<0.003)$ and HCLP $(p<0.0002)$. Considering yields at depleted substrate, HCHP Average yields were 959,4 units, LCHP Average yields were 607 units and HCLP Average yields were 132,2 units. Fig. V shows what said above.

The average adult quantity at maximum average slope of cumulative frequency curve was the highest for HCHP, compared to LCHP $(\mathrm{p}<0.0005)$ and HCLP $(\mathrm{p}<0.0002)$. Average values were respectively: 871.4, 518.6 and 124 specimens.

\section{ADULT MORTALITY}

Adult mortality was influenced by diet $(\mathrm{p}<0.0003)$ : Mortality ranged from $1.86 \%$ to $3.47 \%$ for $\mathrm{HCHP}$, with an average value of $2.81 \%$; from $1.27 \%$ to $7.87 \%$ for LCHP, with an average value of $5.12 \%$; from $8.06 \%$ to $16.78 \%$ for HCLP, with an average value of $12.62 \%$. Differences between HCHP and LCHP were not statistically significant, we had instead significant differences comparing HCHP and HCLP, with a p-value $<0.0005$; also when comparing LCHP with HCLP we obtained significant differences $(p<0.003)$.

\section{FIRST ADULTS APPEARANCE TIME}

First adults appearance time did not show statistical significance. Values were all quite comparable, ranging from 33 to 40 for HCHP, from 38 to 43 for LCHP and from 35 to 46 days for HCLP. Average values were 35.6 for HCHP, 41.2 for LCHP and 39.8 days for HCLP. These values were lower than the ones obtained by SALLET et al. (2013) (55 days).

\section{FEED CONVERSION RATIO}

Feed conversion ratio was different among the diet templates $(p<0.008)$ : it was similar and not statistically significant comparing HCHP and LCHP, but heavily different comparing HCHP and HCLP $(p=0.01219)$ and LCHP to HCLP $(p=0.01219)$. Average FCR values were 3.56 for HCHP, 2.73 for LCHP and 30.71 for HCLP.

\section{CONCLUSIVE CONSIDERATIONS}

This study shows that the nutrient content of artificial diets greatly affects many biological aspects in rearing $A$. diaperinus. Diets with high protein content gave the best results in terms of total weight, total quantity and adult mortality; this is also confirmed by the recent results of VAN BRoEKHOVEN et al. (2015) and by other studies on the importance of protein content in increasing insects' growth rate (DAVIS and Sosulski, 1974; MoRALES-RAMOs et al., 2010). Furthermore, average quantity and weight yields were also higher on high protein templates. 


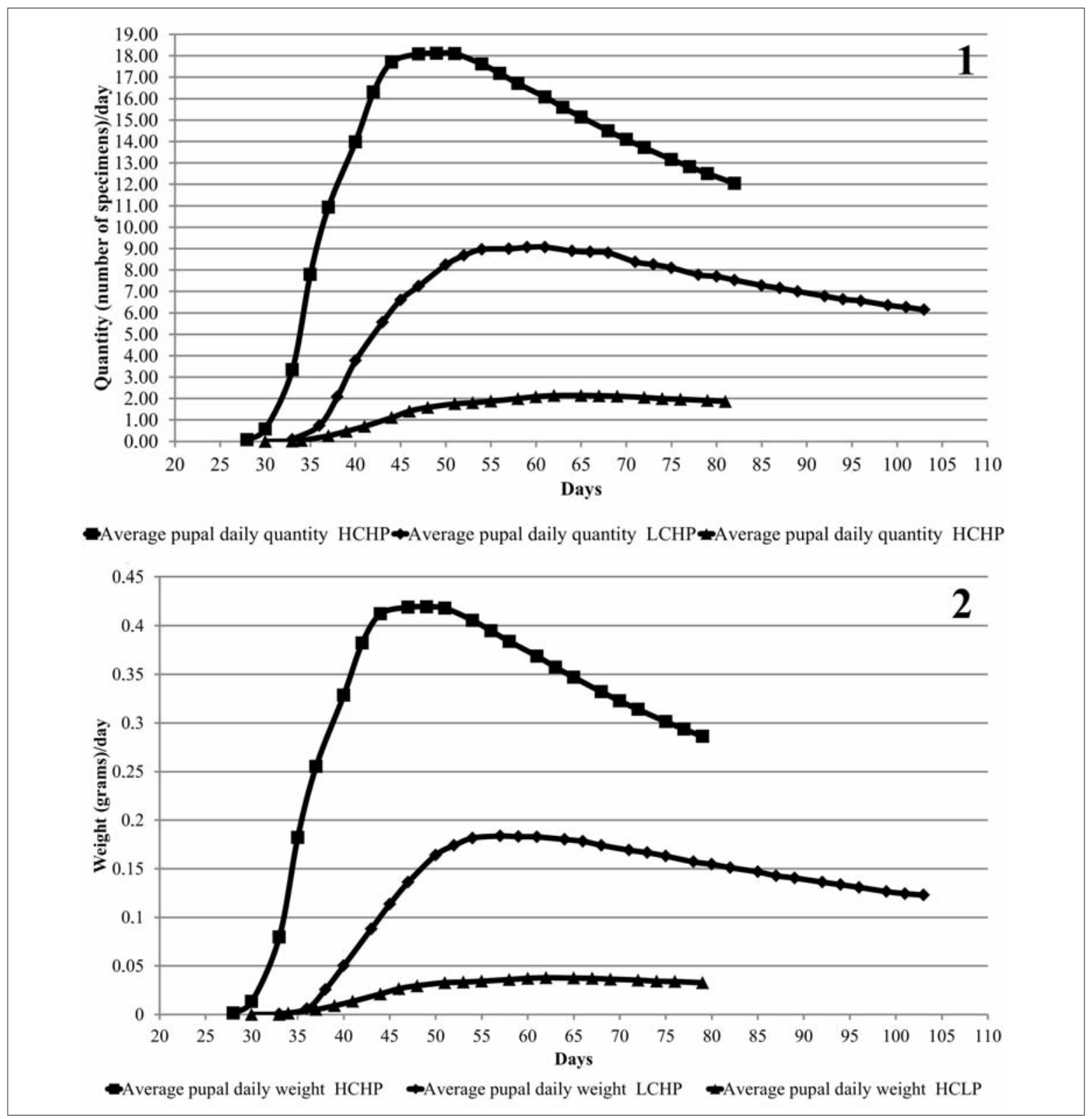

Fig. III - (1) Average pupal daily quantity calculated as pupae/day ratio. (2) Average pupal daily weight calculated as weight/day ratio $(\mathrm{HCHP}=$ high carbohydrates, high proteins; $\mathrm{LCHP}=$ low carbohydrates, high proteins; HCLP $=$ high carbohydrates, low proteins).

Energy content in templates seems not so important as macronutrient composition to the final results: HCLP had a higher energy content than LCHP, but produced poor results while HCHP and HCLP templates had almost the same energy value but yields were, in all respects, higher in HCHP. Although cereals flours acted as feeding stimulants (MURRAY, 1960), the low protein content and the probable presence of anti-nutrients were, all together, the reasons for so poor results with the HCLP template. FCR obtained is positioned midway between poultry (2.0) and pigs (3.6) and it is definitely lower than beef (7.8), (WILKINSON, 2011). Moreover the edible part of $A$. diaperinus $(100 \%)$ is greater than breeding stock (ca 50\%, DE VRIES and DE BoER, 2010), making it more efficient for production purposes. Our results show that many other studies would be desirable, focusing on the individual species characteristics, necessary to improve the diets for rearing insects in order to increase the industrial productivity for food and feed purposes.

\section{REFERENCES}

ADENIJI A.A., 2008 - The feeding value of rumen contentmaggot meal mixture in the diets of early weaned piglets. - Asian J. Anim. Vet. Adv., 3: 115-119.

Anderson S.J., 2000 - Increasing calcium levels in cultured insects. - Zoo Biol., 19: 1-9.

Applebaum S.W., 1966 - Digestion of potato starch by larvae of the flour beetle, Tribolium castaneum. - J. Nutr., 90: 235-239.

BALlitoc D.A., Sun S., 2013 - Ground yellow mealworms (Tenebrio molitor L.) feed supplementation improves growth performance and carcass yield characteristics in broiler. - Open Science Repository Agriculture Online.

Bayandina G.V., Inkina Z.G., 1980 - Effects of prolonged use of housefly larvae in the diet of sows and their offspring on fattening and meat quality of the 


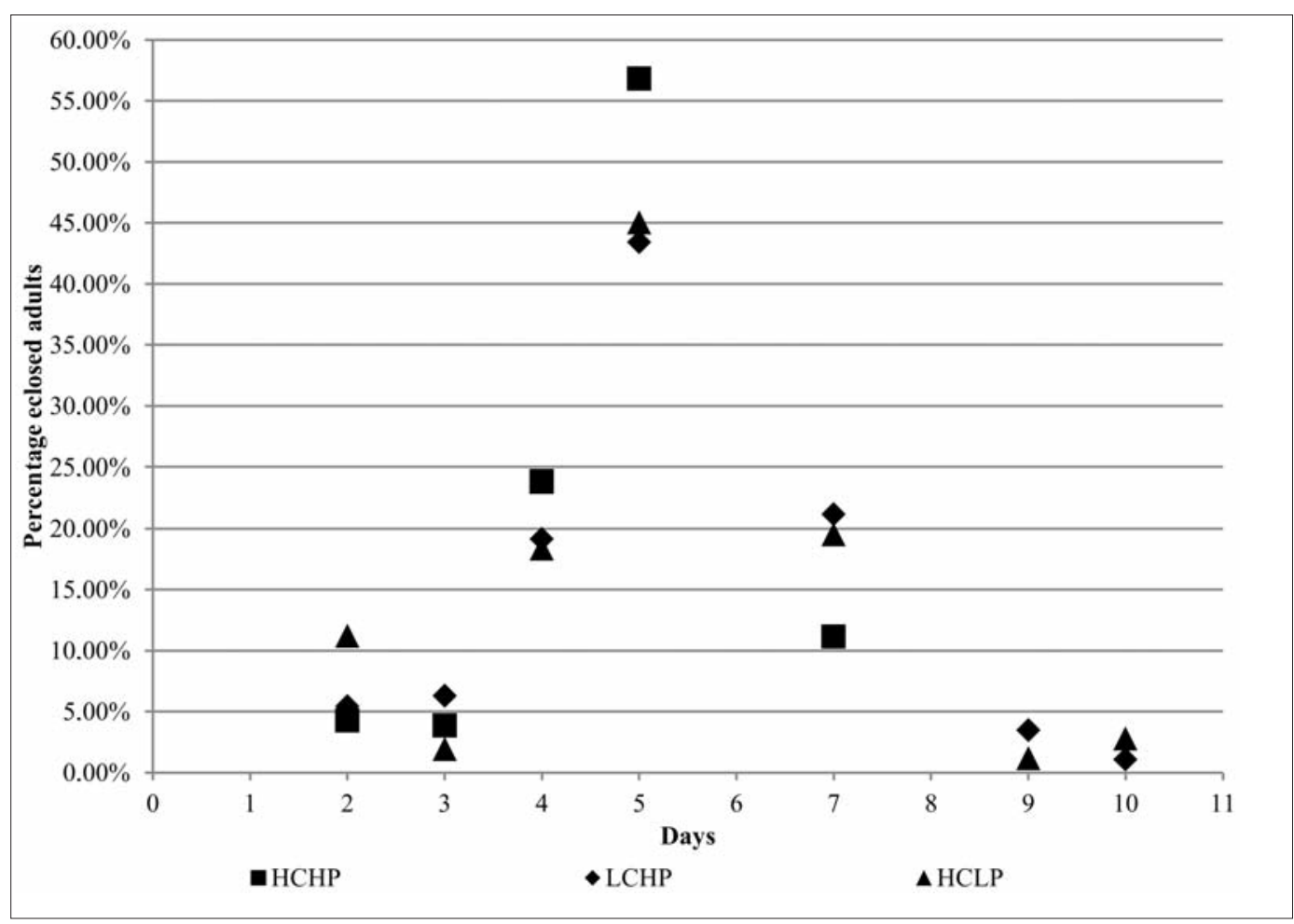

Fig. IV - Time needed for pupal metamorphosis expressed as percentage of total adults (HCHP $=$ high carbohydrates, high proteins; LCHP= low carbohydrates, high proteins; HCLP= high carbohydrates, low proteins).

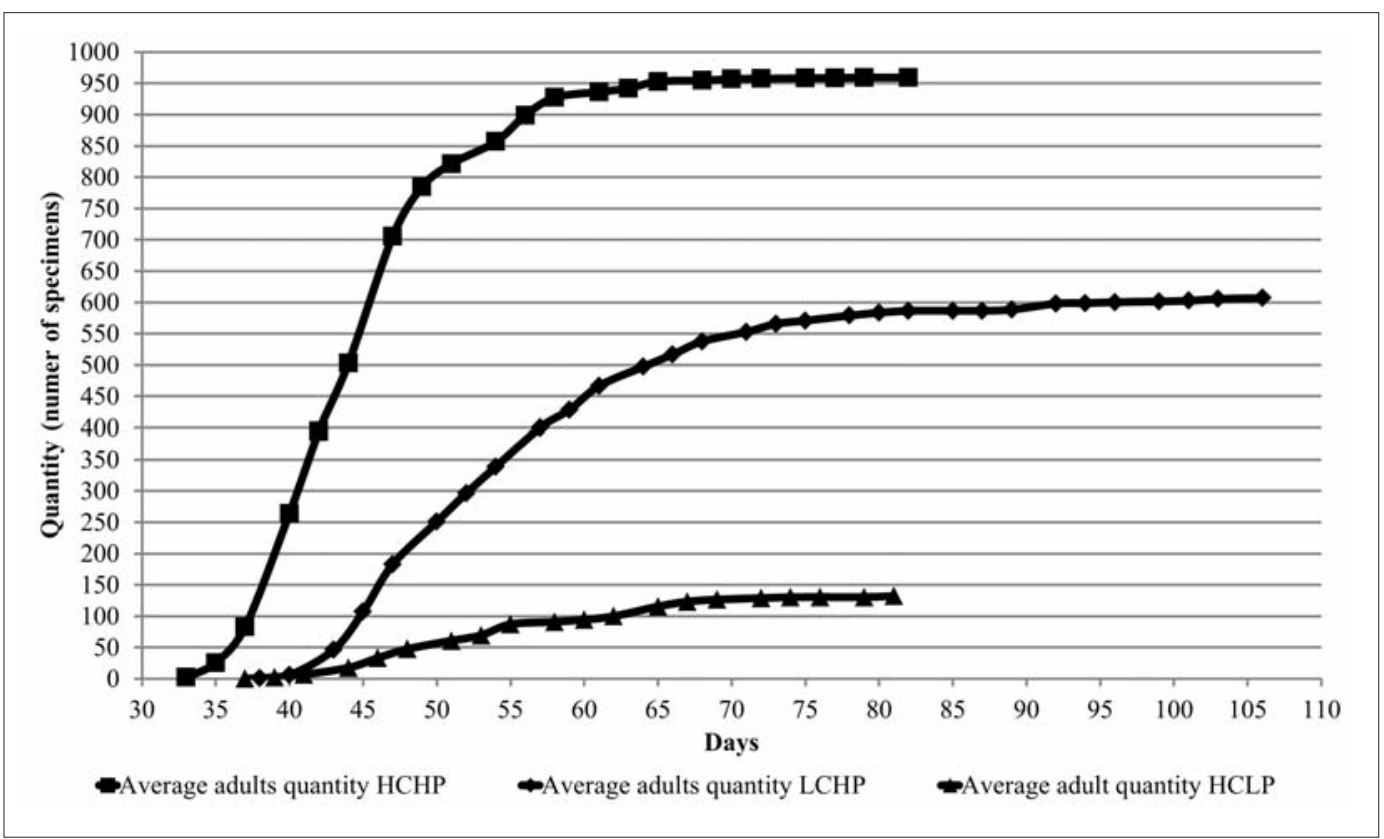

Fig. V - Cumulative frequency curves of average adult quantity in diet templates ( $\mathrm{HCHP}=$ high carbohydrates, high proteins; $\mathrm{LCHP}=$ low carbohydrates, high proteins; HCLP $=$ high carbohydrates, low proteins).

young. - Nauchnye Trudy Novosibirskogo Sel'skokhozyaistvennogo Inst., 134: 52-59.

BONDARI K., SHEPPARD D.C., 1981 - Soldier fly larvae as feed in commercial fish production. - Aquaculture, 24: 103-109.

BONDARI K., SHEPPARD D.C., 1987 - Soldier fly, Hermetia illucens L., larvae as feed for channel catfish, Ictalurus punctatus (Rafinesque), and blue tilapia, Oreochromis aureus (Steindachner). - Aquac. Res., 18: 209-220
Chernaki-Leffer A.M., LAZZari F.A., LAZZAri S.M.N., AlmeIDA L.M., 2001 - Controlling the mealworm. - Avic. Ind., 1094: 22-25.

CoHEN A.C., 2004 - Insect Diets; Science and Technology. CRC PRESS, $344 \mathrm{pp}$.

Dass R., Paul A.V.N., Agarwal R.A., 1984 - Feeding potential and biology of the lesser mealworm, Alphitobius diaperinus, preying on Corcyra cephalonica St. (Lep. Pyralidae). - Z. Angew. Entomol., 98: 444- 447. 
DAVIS G.R.F., SoSULSKI F.W., 1974 - Nutritional quality of oilseed protein isolates as determined with larvae of the yellow mealworm, Tenebrio molitor L. - J. Nutr., 104: $1172-1177$.

De Marco M., Rotolo L., Gasco L., Belforti M., Gai F., Martinez S., Madrid J., Hernandez F., Katz H., Zoccarato I., Schiavone A., 2014 - Apparent digestibility and metabolizable energy of two different insects meal (Hermetia illucens and Tenebrio molitor) in broiler chickens. In: 18th Congress of the European Society of Veterinary and Comparative Nutrition. 11-13 September, Utrecht, Netherlands.

De Vries M., De Boer I.J.M., 2010 - Comparing environmental impacts for livestock products: a review of life cycle assessments. - Livest. Sci., 128: 1-11.

FAsAKin E.A., Balogun A.M., Ajayi O.O., 2003 Evaluation of full-fat and defatted maggot meals in the feeding of clariid catfish Clarias gariepinus fingerlings. Aquac. Res., 34: 733-738.

FUNKE B.R., 1983 - Mold control for insect-rearing media. - Bull. Entomol. Soc. Am., 29: 41-44.

GaO H.L., Li H.T., Zhang L., HaO M.J., 2010 - Effects of Tenebrio molitor $L$. larva decomposing polystyrene foam. - Adv. Mat. Res., 113-114: 1972-1975.

Gasco L., Belforti M., Rotolo L., Lussiana C., Parisi G., Terova G., Roncarati A., Gai F., 2014 - Mealworm (Tenebrio molitor) as a potential ingredient in practical diets for rainbow trout (Oncorhynchus mykiss). In: Insects to Feed the World, Vantomme P., Munke C., van Huis A. Eds., Wageningen University, Ede-Wageningen, The Netherlands, pp. 69

Gasco L., Gai F., Piccolo G., Rotolo L., Lussiana C., Molla P., Chatzifotis S., 2014b - Substitution of fishmeal by Tenebrio molitor meal in the diet of Dicentrarchus labrax juveniles. In: Insects to Feed the World, Vantomme P., Munke C., van Huis A. Eds., Wageningen University, Ede-Wageningen, The Netherlands, pp. 70.

GHaly A.E., AlKOAIK F.N., 2009 - The yellow mealworm as a novel source of protein. - Am. J. Agr. Biol. Sci., 4: 319-331

Gaston K.J. \& CHOwn S.L., 1999 - Elevation and climatic tolerance: a test using dung beetles. - Oikos, 86: 584-590.

HwangBo J., Hong E.C., Jang A., Kang H.K., OH J.S., KIM B.W., PARK B.S., 2009 - Utilization of house fly-maggots, a feed supplement in the production of broiler chickens. J. Environ. Biol., 30: 609-614.

Hosen M., Khan A.R., Hossain M., 2004 - Growth and development of the lesser mealworm, Alphitobius diaperinus (Panzer) (Coleoptera: Tenebrionidae) on cereal flours. - Pak. J. Biol. Sci., 7: 1505-1508.

MeKonnen M.M., HoEKstra A.Y., 2010 - The green, blue and grey water footprint of farm animals and animal products. Value of Water Research Report Series 48. UNESCO-IHE, Delft, The Netherlands, $50 \mathrm{pp}$.

Mela D.J., 1999 - Food choice and intake: the human factor. - Proc. Nutr. Soc., 58: 513-521.

Mereiles E.A., Carneiro C.N.B., Damatta R.A., SAmuels R.I., SILVA C.P., 2009 - Digestion of starch granules from maize, potato and wheat by larvae of the Yellow mealworm, Tenebrio molitor and the Mexican bean weevil, Zabrotes subfasciatus. - J. Insect Sci., 9: 43.

Mignon J., 2002 - L'entomophagie: une question de culture? - Tropicultura, 20: 151-155.

MURRAY D.R.P., 1960 - The stimulus to feeding in larvae of Tenebrio molitor L. - J. Insect Physiol., 4: 80-91.

Morales-Ramos J.A., Rojas M.G., Shapiro-Ilan D.I.,
TEDDERS W.L., 2010 - Developmental plasticity in Tenebrio molitor (Coleoptera: Tenebrionidae): analysis of instar variation in number and development time under different diets. - J. Entomol. Sci., 45: 75-90.

NaKagaki B.J., Defoliart G.R., 1991 - Comparison of diets for mass-rearing Acheta domesticus (Orthoptera: Gryllidae) as novelty food, and comparison of feed conversion efficiency with values reported for livestock. J. Econ. Entomol., 84: 891-896.

Newton G.L., Booram C.V., Barker R.W., Hale O.M., 1977 - Dried Hermetia illucens larvae meal as a supplement for swine. - J. Anim. Sci., 44: 395-40

Newton L., Sheppard C., Watson D.W., Burtle G., Dove R., 2005 - Using the black soldier fly, Hermetia illucens, as a value-added tool for the management of swine manure. In: Report for Mike Williams, Director of the Animal and Poultry Waste Management Center. North Carolina State University.

Ogunj J.O., Nimptsch J., Wiegand C., Schulz C., 2007 Evaluation of the influence of housefly maggot meal (magmeal) diets on catalase, glutathione $S$ transferase and glycogen concentration in the liver of Oreochromis niloticus fingerling. - Comp. Biochem. Phys. A, 147: 942-947.

OONINCX D.G.A.B., DE BoER I.J.M., 2012 - Environmental impact of the production of mealworms as a protein source for humans - a life cycle assessment. - PLoS One, 7: e51145.

OonincX D.G.A.B., Van ItTerbeeck J., HeetKamp M.J.W., Van Den Brand H., Van LoOn J.J.A., Van Huis A., 2010 - An exploration on greenhouse gas and ammonia production by insect species suitable for animal or human consumption. - PLoS One 5: e14445.

Piccolo G., Marono S., Gasco L., Iannaccone F., Bovera F., Nizza A., 2014 - Use of Tenebrio molitor larvae meal in diets for Gilthead seabream Sparus aurata juveniles. In: Insects to Feed the World, Vantomme P., Munke C., van Huis A. Eds., Wageningen University, Ede-Wageningen, The Netherlands, pp. 68.

Ramos-Elorduy J., Gonzalez E.A., Hernandez A.R., PINO J.M., 2002 - Use of Tenebrio molitor (Coleoptera: Tenebrionidae) to recycle organic wastes and as feed for broiler chickens. - J. Econom. Entomol., 95: 214-220.

Rice S. J., LAmBKin T. A., 2009 - A new culture method for lesser mealworm, Alphitobius diaperinus. - J. Appl. Entomol., 133: 67-72.

Rozin P., FALlon A.E., 1987 - A perspective on disgust. Psychol. Rev., 94: 23-41.

Sallet L.A.P., Araujo M., Monnerat R., 2013 Settlement Alphitobius diaperinus Panzer, 1779 (Coleoptera: Tenebrionidae) on Different Diets in the Laboratory. - Bioscience Methods, 4: 34-39.

Schiavone A., De Marco M., Rotolo L., Belforti M., Martinez Mirò S., Madrid Sanchez J., Hernandez Ruiperez F., Bianchi C., Sterpone L., Malfatto V., Katz H., Zoccarato I., Gai F., Gasco L., 2014 Nutrient digestibility of Hermetia illucens and Tenebrio molitor meal in broiler chickens. In: Insects to Feed the World, Vantomme P., Munke C., van Huis A. Eds., Wageningen University, Ede-Wageningen, The Netherlands, pp. 73

Silva A.S., Hoff G., Doyle R.L., Santurio J.M., MonTEIRO S.G., 2005 - Biological cycle of the mealworm Alphitobius diaperinus laboratory - Acta Sci. Vet., 33: 177-181

Singh P., House H.L., 1970a - Antimicrobials: "safe" levels in a synthetic diet of an insect, Agria affinas. - J. Insect Physiol., 16: 1769-1782. 
Singh P., House H.L., 1970b - Antimicrobial agents: their detrimental effects on size of an insect, Agria affinis. Can. Entomol., 102: 1340-1344.

Steinfeld H., Gerber P., Wassenaar T., Castel V., Rosales M. De HaAn C., 2006 - Livestock's long shadow: Environmental Issues and Options; Food and Agricultural Organisation of the United Nations, Rome, Italy, $390 \mathrm{pp}$.

USDA 2016 - https://ndb.nal.usda.gov/

Van Broekhoven S., Oonincx D.G.A.B., Van Huis A., VAN LOON J.J.A., 2015 - Growth performance and feed conversion efficiency of three edible mealworm species (Coleoptera: Tenebrionidae) on diets composed of organic by-products. - J. Insect Physiol., 73: 1-10

VAn Huis A., 2013 - Potential of insects as food and feed in assuring food security. - Annu. Rev. Entomol., 58: 563583.
Van Huis A., Van Itterbeeck J., Klunder H., Mertens E., Halloran A., Muir G., Vantomme P., 2013 - Edible Insects: Future Prospects for Food and Feed Security. Food and Agricultural Organization of the United Nations, $201 \mathrm{pp}$.

Viroje W., MALIN S., 1989 - Effects of fly larval meal grown on pig manure as a source of protein in early weaned pig diets. - Thurakit Ahan Sat, 6: 25-31.

WILKINSON J.M., 2011 - Re-defining efficiency of feed use by livestock. - Animal, 5: 1014-1022.

YEN A.L., 2009 - Edible insects: traditional knowledge or western phobia? - Entomol. Res., 39: 289-298.

Zuidhof M.J., Molnar C.L., Morley F.M., Wray T.L., Robinson F.E., Khana B.A., Al-Ani L., GoOnEwardene L.A., 2003 - Nutritive value of house fly (Musca domestica) larvae as a feed supplement for turkey poults. - Anim. Feed Sci. Technol., 105: 225-230. 
